\title{
Applied Engineering Using Schumann Resonance for Earthquakes Monitoring
}

\author{
Jose A. Gazquez ${ }^{1,2}$, Rosa M. Garcia ${ }^{1,2}$, Nuria N. Castellano ${ }^{1,2}$ (D), Manuel Fernandez-Ros ${ }^{1,2}$ (iD, \\ Alberto-Jesus Perea-Moreno ${ }^{3}$ (D) and Francisco Manzano-Agugliaro ${ }^{1, *}$ \\ 1 Department Engineering, University of Almeria, CEIA3, 04120 Almeria, Spain; jgazquez@ual.es (J.A.G.); \\ rgarciasalvador@ual.es (R.M.G.); nnovas@ual.es (N.N.C.); mfr460@ual.es (M.F.-R.) \\ 2 Research Group of Electronic Communications and Telemedicine TIC-019, 04120 Almeria, Spain \\ 3 Department of Applied Physics, University of Cordoba, CEIA3, Campus de Rabanales, 14071 Córdoba, \\ Spain; aperea@uco.es \\ * Correspondence: fmanzano@ual.es; Tel.: +34-950-015396; Fax: +34-950-015491
}

Received: 14 September 2017; Accepted: 25 October 2017; Published: 27 October 2017

\begin{abstract}
For populations that may be affected, the risks of earthquakes and tsunamis are a major concern worldwide. Therefore, early detection of an event of this type in good time is of the highest priority. The observatories that are capable of detecting Extremely Low Frequency (ELF) waves $(<300 \mathrm{~Hz})$ today represent a breakthrough in the early detection and study of such phenomena. In this work, all earthquakes with tsunami associated in history and all existing ELF wave observatories currently located worldwide are represented. It was also noticed how the southern hemisphere lacks coverage in this matter. In this work, the most suitable locations are proposed to cover these geographical areas. Also, ELF data processed obtained from the observatory of the University of Almeria in Calar Alto, Spain are shown. This is a contribution to help protect against natural disasters such as those caused by earthquakes and tsunamis.
\end{abstract}

Keywords: ELF wave; Schumann resonance; ELF sensor; earthquakes alerts; worldwide

\section{Introduction}

The global belt of Earth's subduction zones is the region is where most of the most destructive earthquakes and tsunamis occur. The magnitude (M) of an earthquake is the most important factor that determines its violence and destructiveness, but that is not always the case; a relatively low magnitude earthquake may be devastating in a given zone, since construction criteria in the zone must be accounted for, among other factors. In addition, great tsunamis or large earthquakes $(M>8.0)$ are usually generated whenever extensive areas of the subduction megathrust face a rupture [1]. There are examples of earthquake-produced tsunamis in the 2004 Sumatra earthquake (M-9.0) [2], accounting for 220,000 casualties, or in 2006, with the tsunami that developed from the Java earthquake (M-7.8) [3]. The intensity and destruction capacity of earthquakes and tsunamis are estimated by considering the area of vertical uplift of the sea bed, and these magnitudes are related to the geometry of the slipping fault when the earthquake rupture is located near the sea floor [4]. Seismic events produce variations in the magnetic field as well; the study of electromagnetic phenomena precursory of earthquakes and volcanic eruptions has been a very active subject during the last years [5]. Examples of this being the observation of Ultra Low Frequency (ULF) anomalies $(300 \mathrm{~Hz}-3000 \mathrm{~Hz})$ prior to the development of the Loma Prieta earthquake in 1989 near San Francisco [6,7]; later a geomagnetic field variation of 7.2 nT was detected approximately $7 \mathrm{~min}$ before the Tohoku earthquake occurred in 2011 and detected by the Iwaki observatory, at $210 \mathrm{~km}$ from the epicenter [8-10]. Another example is the possible detection of a series of pre-earthquakes magnetic anomalies that occurred on 25 April 2015, with epicentre in Nepal and a 7.8 magnitude. Detection was possible through the use of the Swarm magnetic satellites [11]. 
In addition, after the Fukushima Daiichi nuclear plant disaster and the Great East Japan Earthquake Tsunami, which occurred in 11 March 2011, the requirement of cover human-environment symbiotic points is very important [12].

Tsunamis also have a major impact on economic aspects. After a tsunami occurs the flooding of the surrounding lands by seawater is common, damaging those lands and destroying plot borders. This causes damage to property rights and to the land administration system in general [13]. Therefore, after a Tsunami, it is necessary to re-establish the property lines again, using Global Positioning System (GPS) normally, as was the case in Indonesia [14]. From a geodesic point of view, it is well known that the definitive displacement of the zones near the epicentre is the results of earthquakes [15], e.g., the postseismic deformation after 2008 Wencham earthquake in China [16], or postseismic changes in Thai geodetic network owing to the Sumatra-Andaman mega-thrust earthquake in 2004 [17] and the Nias earthquake in 2005 [18].

Mega-splay faults are caused when very extensive thrust faults rising from the plate frontier megathrust intersects the seafloor along the lower earring of the margin. It has been hypothesized that these mega-splay faults transfer displacement efficiently to the near surface, contributing to the genesis of seismic phenomena. Recently, these facts have been identified as first order characteristics in the Nankai Trough [19], and are usual in other subduction areas such as Alaska [20], Sunda [21], and Colombia [22].

To understand the development of tsunamis during the formation of large earthquakes, it is necessary to determine the exact location of the slip of the decomposition system, called splay-frontal [23]. Instrumental measurements of earthquake and tsunamis largely come from tide seismological and gauge observatories and lately, bottom pressure recorders located in the deep ocean. The first time that the satellites Jason- 1 and Topex-Poseidon collected transects of sea-height data using radar altimeter was in the 2004 Indian Ocean tsunami. These data showed a tsunami signal during the across the Indian Ocean [24]. The number of publications based on earthquake monitoring increases significantly and becomes a topic of increasing interest in the last decade [25,26].

Some authors suggest that a probabilistic approach might be a method for assessing the risk posed by seismic phenomena for a wide range of magnitudes [27]. Due to the relationship between earthquakes and tsunamis, both the recurrence allocation of events in time and the delivery of earthquake or landslide sizes can be used to calculate the tsunami probability. In coastal locations with a broad register of tsunami is the distribution scope that is similar to the ones from other natural damage such as landslides, forest fires, and earthquakes [1], which could be described as a power law [28]. But apart from this approach, methods for early detection are needed.

Sensors can collect data to detect seismic phenomena that can lead to major natural disasters by means of a suitable seismic system and a correct treatment of the information. In addition, these systems could help with the early detection of a disaster, supporting the decisions to minimize human and environmental damage [12]. In the literature there are several types of sensor systems that measure different environmental responses after an earthquake and could determine the material damage caused. An example is the sensor Structural Health Monitoring (SHM), which measures the acceleration of the response movement of a building after an earthquake [29]; other sensors measure post-seismic deformations in horizontal structures [30] or in vertical structures [31].

Early detection of this type of seismic events can help save many lives. One such method of early detection could be the presence of ELF wave's observatories, because of the relationship between Very Low Frequency/Extremely Low Frequency (VLF/ELF) waves and seismic phenomena [32,33]. During the eruption of the in the Kelud volcano eruption, seismic signals showing peaks at $3.7 \mathrm{mHz}, 4.8 \mathrm{mHz}$, $5.7 \mathrm{mHz}$, and $6.8 \mathrm{mHz}$ were observed in Indonesia. This fact suggests that an ionosphere-atmosphere coupling phenomenon was present along with the lithosphere-atmosphere coupling [34]. In addition, mentioning that such electromagnetic phenomena might be used to predict earthquakes, an example of this is shown in the precursors of the Loma-Prieta earthquake [35], or for the Great East Japan earthquake of 2011 (or Tohoku earthquake) [36]. 
The aim of this paper is to represent the major worldwide earthquakes and tsunamis of twentieth and twenty-first centuries, and to show the location of ELF wave's observatories existing in the world accounting for the relationship between the two phenomena. This allows us to visualize the zones high probability of seismic phenomena. Taking into consideration the presence of seismic phenomena and their possible detection, different areas of the world will be shown which are suited to this kind of observatories.

\section{Materials and Methods}

\subsection{Seismic Phenomena and ELF Waves}

The importance of the study of precursors or indicators of seismic activity is a key to early detecting and preventing succession of major disasters [37].

Seismic events can be related to different types of events. There is evidence indicating that a link between the lithosphere-atmosphere-ionosphere occurs before the occurrence of seismic events [38]. Understanding these processes' physics and possibility of it being used to develop an early detection system is the subject of great research and development in recent decades. It has demonstrated the influence of seismic events on this type of ELF signals, setting both types of signals artificially and analyzing the behavior of electromagnetic waves when they are motivated by earthquakes [32]. One of the first attempts to standardize ELF wave monitoring on a global scale dates back to 1985, thus it is considered a fairly developed work topic in recent years [39].

Also, there exist other publications that detect anomalies in signals produced by the seismic phenomenon. One example is the correlation between the seismic phenomena and the Outgoing Long-wave Radiation (OLR) data. These signals can be observed by satellites [16], such as the case of the Chinese Earthquake (Wenchuan and Lushan earthquakes) that occurred between 2006 and 2013.

The detection of such anomalies can also be carried out by observatories or ELF/VLF stations [33]. These observatories are located in very low-noise locations. In them, the ELF/VLF range (signals up to $300 \mathrm{~Hz})$ and the orthogonal components of the magnetic field $\left(\mathrm{B}_{\mathrm{x}}, \mathrm{B}_{\mathrm{y}}\right.$ and $\left.\mathrm{B}_{\mathrm{z}}\right)$ can be measured. Three orthogonal induction coil magnetometers are normally employed. The $B_{x}$ component usually represents the North-South (NS) geomagnetic component of the magnetic field. It can be determined by the induction magnetometer whose axis is aligned with the direction NS, so that the component $B_{x}$ is sensitive to waves propagating in the East-West (EW) direction. The other component of interest is the $\mathrm{B}_{\mathrm{y}}$ component that is sensitive to waves propagating in the meridian plane [40]. ELF/VLF signals propagate through the environment, and are detected by an appropriately located ELF/VLF receiver over a zone where enhanced radio emissions are happening prior to a great earthquake. Some studies about ionosphere-atmosphere-groundwater phenomena great earthquakes $(M>6.5)$ associate this occurrence with strong ELF noises or anomalies present in signals located in the ELF frequency band [41].

One of the most important ELF signals, which are affected by the presence of these seismic events is the Schumann Resonance (SR) [42]. These resonances are produced by natural phenomena; they were predicted theoretically in the 50's, but no graphical representation of them was established until 1962 [43]. The SR signals are very weak signals, on the order of PicoTesla, and occur in the space between the earth and the ionosphere, as indicated in Figure 1. This space acts as a resonant cavity or waveguide for these signals, since it has a finite or limited size [44]. 


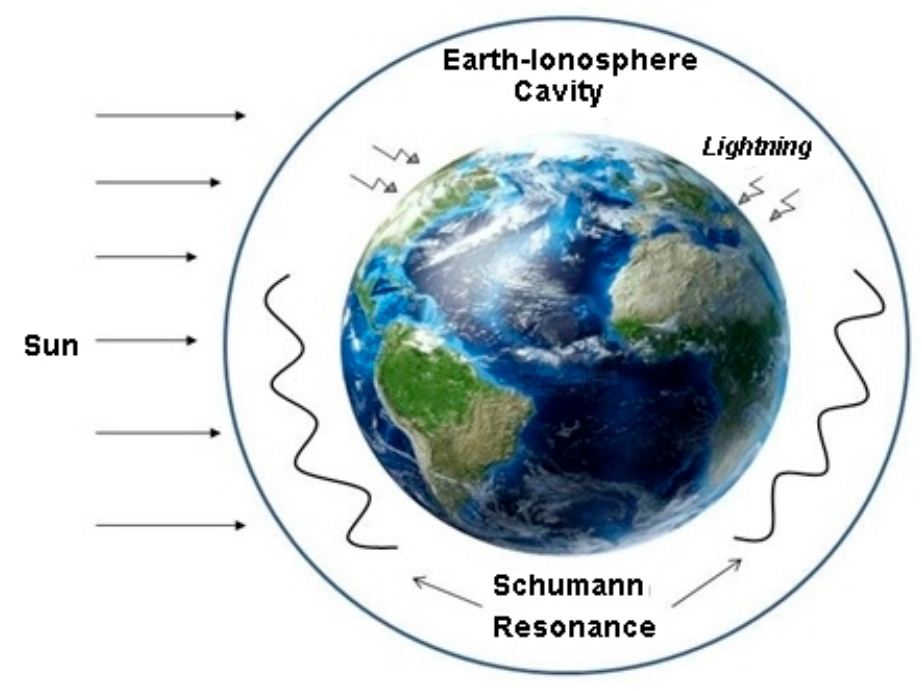

Figure 1. Phenomenon of Schumann Resonance.

The measurement of these signals allows developing various applications. This includes determining the global lightning activity or storms by diurnal variations in the amplitude of the signal continuous records [45], or the study of planetary electromagnetic environment [46]. Another application of SR signals that has aroused great interest in recent years is as a global tropical thermometer. Since a frequency shift of resonance peaks has been observed related to the global temperature increase of the planet or global warming [47].

In regards to the relationship between the mean of these phenomena ELF and the existence of seismic events, there are relatively recent works showing the appearance of abnormal variations in the amplitude and phase of these ELF signals when crossing regions of certain seismic activity. These changes are due to displacement of the inner boundary of the ionosphere in a few kilometers when seismic activity occurs [48].

Other publications have shown the fact of the signals derived from this phenomenon in a period in which large earthquakes occurred, such as the case developed and understood in Taiwan between 1999 and 2004. It is noted that earthquakes produce a variation of about $1 \mathrm{~Hz}$ in the localization of the peak frequency. Another anomaly that is detected in this type of work is an atypical amplitude increase of all its modes, highlighting the variation in the fourth mode of resonance, as observed in large earthquakes $M>6$ [49]. Other publications indicate that the monitoring this signal allows the checking of the existence of depressions in the frequency of the fourth mode resonance occurring between two and six days before one of the study earthquakes [50]. In most of the works, variations or anomalies in these signals can be observed with days or even weeks in advance before the occurrence of any earthquake. For example, variations have been detected three weeks before the earthquake that happened on the 11 of March 2011, with an 8.9 magnitude in front of the Japanese coast [51]. Signals anomalies were detected for few days, as well ahead before the Sichuan earthquake that took place with a magnitude of 8.0 [52], and the Kobe earthquake of 6.0 magnitude in 2013 [53].

Therefore, the study and analysis of these signals ELF may be a method for detecting seismic events. The presence of ELF stations or observatories in regions with seismic activity or nearby is useful, so that detection is more effective, despite the resonance phenomenon being a global one.

\section{ELF Sensor}

ELF sensors are built by combining vertical electric field sensors and horizontal magnetic induction coils [54]. This process is very complex due to the large number of factors involved, such as its low frequency, the weakness of the signal to be detected, the non-uniformity of the ionosphere, the manifestation of natural electromagnetic noise, and the interference caused by industrial zones, 
appearing as background noise in the process [55]. These are some of the reasons behind the small number of ELF sensors compared to other observatories; although that number has increased fourfold since the five observatories accounted for in 1999.

These observatories are located throughout the world. However, the largest concentration of such observatories is in Japan, where the occurrence of seismic events is greater [56]. Many of these observatories are attempting to establish a correlation between the ELF signals measured and seismic activity, and to compare with data from other stations. For this, a correlation is established within the different components of the magnetic field [57], and the development of theoretical models for describing the intensity of the SR by disturbances in the ionosphere over the top of the epicenter of an earthquake. One of these theoretical models is based on ionosphere's vertical conductivity profile model, describing the regular Earth-ionosphere cavity. The possible disturbance is introduced with the modified model. The localized ionosphere modification shows a Gaussian radial dependence; it has a 1-Mm radius, with the decrease reaching $20 \mathrm{~km}$ in the lower ionosphere height over the epicenter of the earthquake (Taiwan). Also, the diffraction problem in the Earth-ionosphere cavity with a disturbance can be resolved by using the Stratton-Chu integral equation [58].

One of these ELF stations has been developed and steadily improved by the research group TIC019 of Almeria University and it is located in Calar Alto (Almeria, Spain), Figure 2. This observatory began operation in 2011, being the first observatory of its kind in Spain.

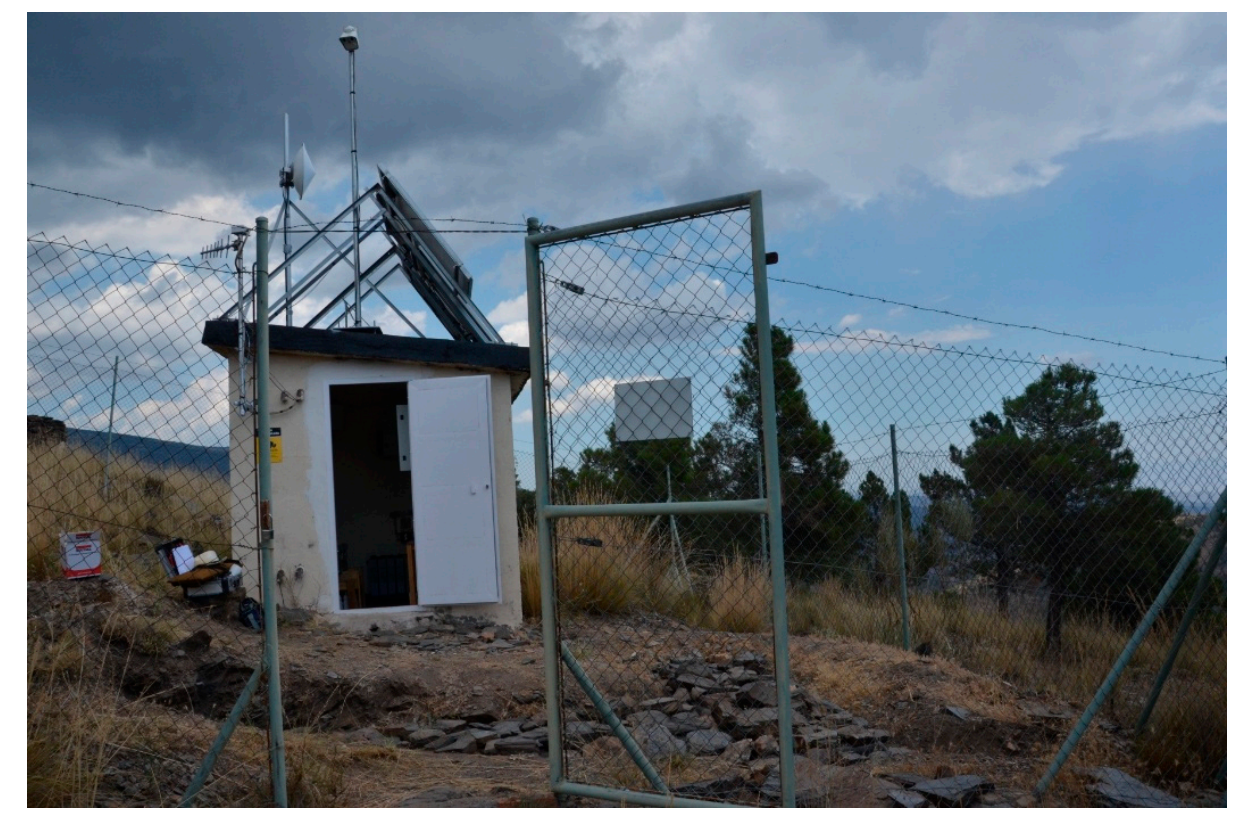

Figure 2. Calar Alto Extremely Low Frequency (ELF) Station (Spain).

The technology used in this type of observatories has evolved significantly in recent years. The general aspects of it are described in a few papers, but only a handful of articles explicitly set the methodology used to capture and measure ELF signals. Figure 3 shows the block diagram of Calar Alto ELF observatory (Almeria, Spain). As the diagram shows, the system consists of a set of stages from signal capture and local real-time processing to transmission to the University of Almeria and the insertion of post-processed data into an interactive database. The stages of the measuring system are as follows:

(1) Signal Capture: formed by the ELF magnetic sensors.

(2) Stage of conditioning: of signal, constituted by a high gain differential amplifier and a level scaled adapter. Through this process a suitable signal is obtained at the input of the next stage, with a maximum dynamic range input and the lowest output clipping. A passband filter ranging from 3 
to $100 \mathrm{~Hz}$ is also included in this stage. This filter attenuates signals outside the desired band, preventing undesired intermodulation or cross-modulation phenomena.

(3) The stage of the Analog/Digital converter (A/D converter): This stage has two channels, one for each sensor. It converts the analog signal into 24-bit samples per channel with a sample rate of 196 samples/s.

(4) The last stage is the data transmission and storage. It is constituted by a local information storage (data logger), which serves as failsafe from temporary interruptions in the transmission system. Additionally it allows data transmission from the A/D converter to the installations of the University of Almeria by means of a digital radio link. In such facilities, the data is inserted into an interactive database for post-processing and study.

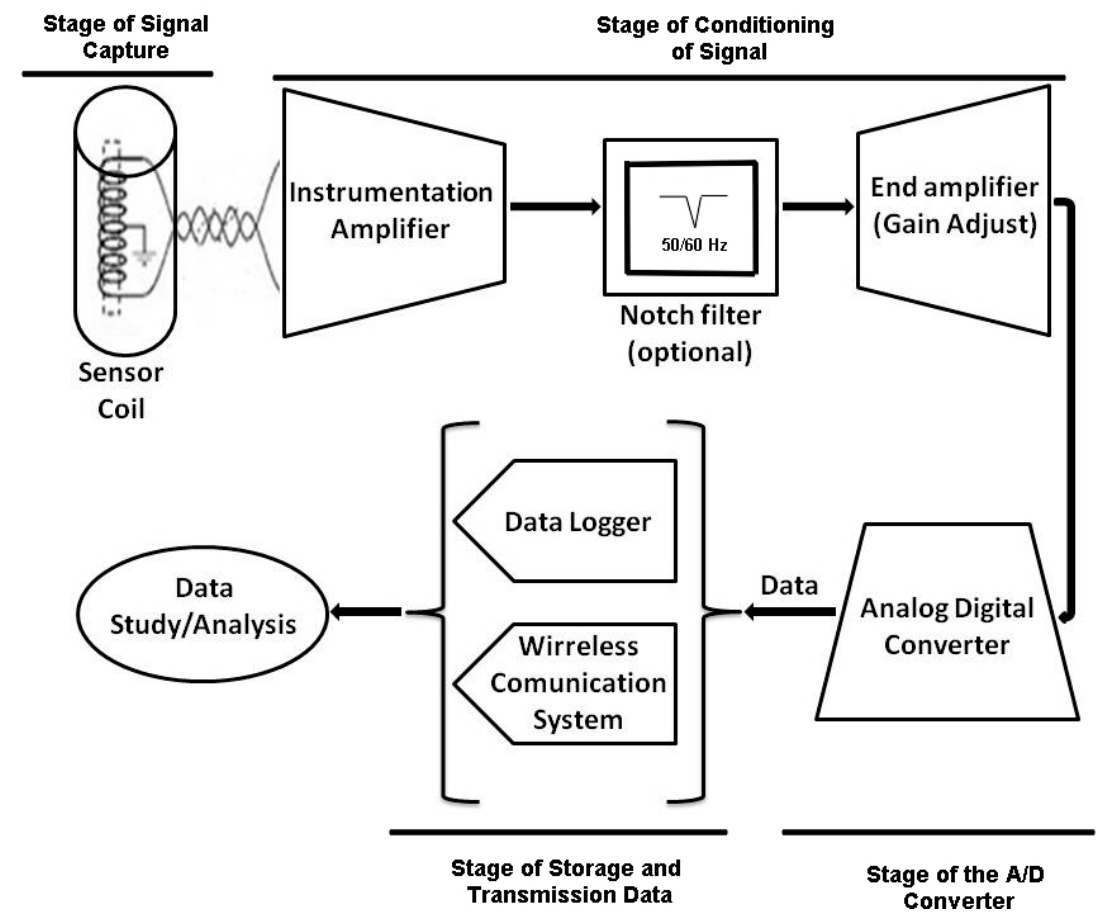

Figure 3. ELF wave sensor diagram.

The magnetic sensors are two magnetic antennas oriented along the main cardinal directions (north-south and east-west). Each sensor is made up of two symmetrical coils that provide balanced differential signals helping to reduce common mode effects $[59,60]$. An optional notch filter was implemented as part of the measurement system using a double Active cell [61] to attenuate the power signals.

The A/D converter system consists of a 24-bit high resolution system that is based on oversampling techniques. The obtained data from the converter is subject to a decimating process through temporary averaging. This causes a reduction in the acquisition noise, as well as in the sampling frequency. By a high-performance embedded Digital Signal Processor (DSP) system is done by this pre-processing. Ultimately, data are sent in real-time by a high-speed link to the research group facilities in Almeria University, where is worked using Power Spectral Density (PSD) estimation techniques [62]. Through the development of this system, the Schumann resonance signal capture efficiency will be enhanced, thereby facilitating their subsequent analysis and study. The data collected from these observatories are like those presented in Figure 4a,b. In these figures, a periodogram and a spectrogram are represented, respectively, recorded from the Calar Alto ELF station (Spain). These representations were established from the data recordings in normal conditions of the day 16 September 2015. The periodogram (Figure 4a) was obtained by 30 min averaging, the result of Fast 
Fourier Transform (FFT) of $20 \mathrm{~s}$ data segments. The $24 \mathrm{~h}$ spectrogram is composed from periodograms that are obtained by averaging each 10-min segments of $20 \mathrm{~s}$.

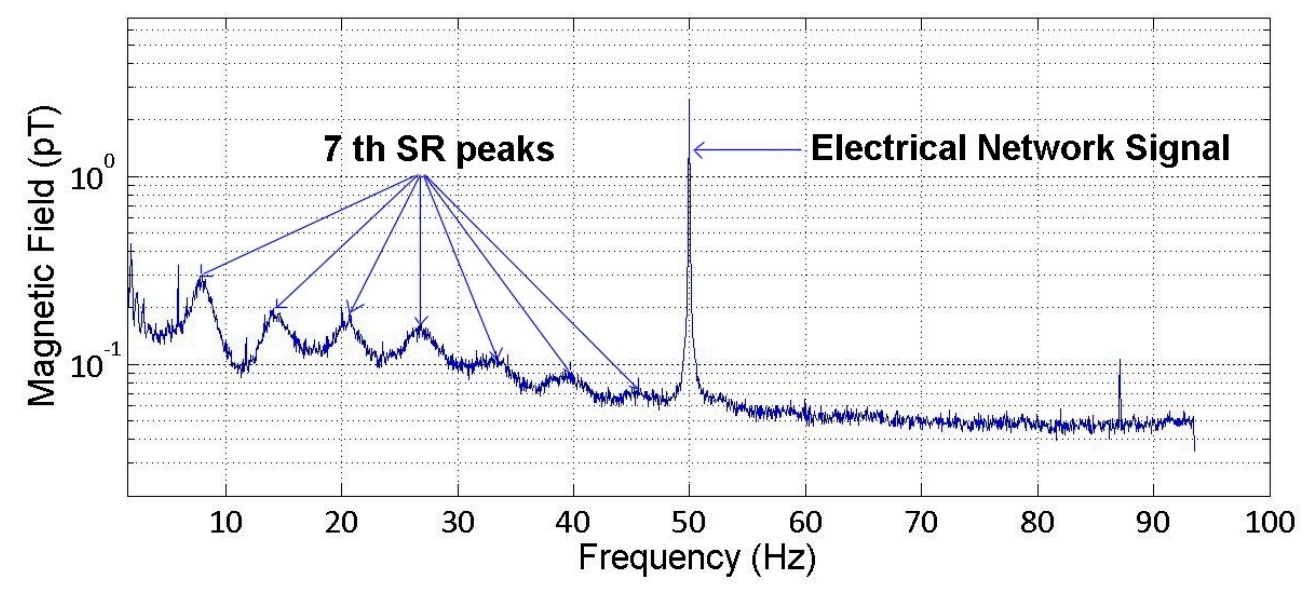

(a)

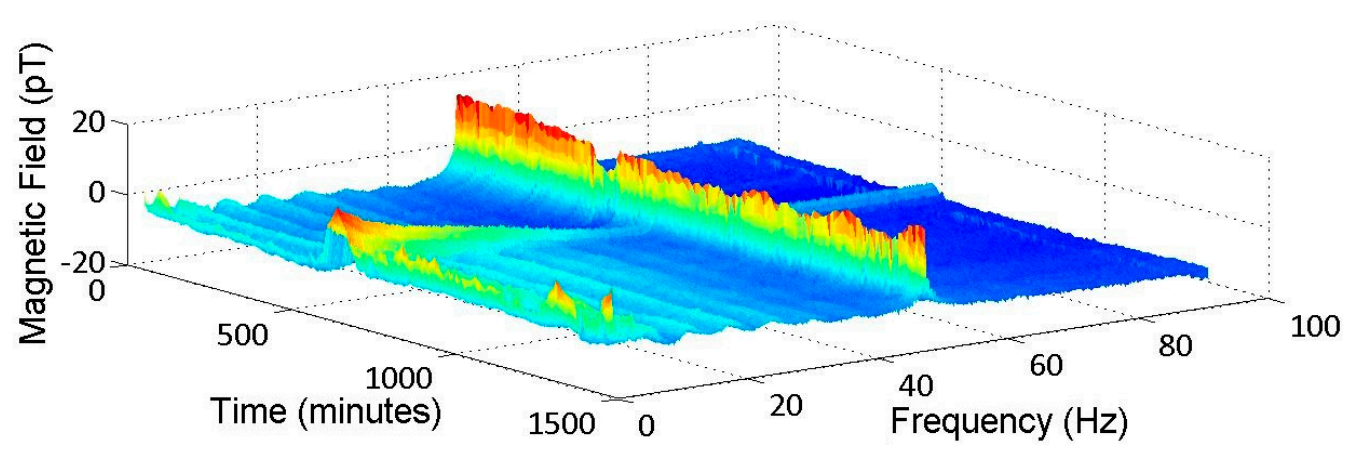

(b)

Figure 4. Data from the Calar Alto Sensor (Spain): (a) The 30 min periodogram. (b) The $24 \mathrm{~h}$ Spectrogram.

In this periodogram, the first 7 resonance peaks can be observed, as well as the signal from the power lines. In the spectrogram, you can see beside the Resonance Schumann modes, variations in power line signals and other signals that affect all frequencies about the $500 \mathrm{~min}$, which is due to strong wind. Therefore, by monitoring the evolution of these electromagnetic signals, we can establish a study of their variation and find out the mechanisms that are related these changes with the occurrence of seismic events. To relate ELF signals' alterations with strong earthquakes, several cases must be studied. The significance of the data would depend on the number of ELF stations around the epicenter, so common ELF alterations could be found and lay out the criteria that might allow early earthquake detection.

\subsection{Worldwide Map of ELF Observatories and Seismic Events}

The number of stations or observatories ELF today is not too large, due to many factors, among which is the difficulty of the measurement process or the study of such signals. This study is an issue that is being widely developed in recent years. ELF/VLF stations or observatories exist today can be classified into several types: 
(a) Observatories that measure the disturbances caused by seismic activity on the ELF radiation, considering subELF observatories. These subELF observatories usually record the possible variations in the Earth's magnetic field, where some have very low frequencies (less than $0.03 \mathrm{~Hz}$ ). An example of this is the station of Uchimura (Japan), which allows for studying the data collected in the range comprised between 0.01 to $0.033 \mathrm{~Hz}$ frequencies [52]. In other publications, the signals of lower frequencies $(0.01-0.02 \mathrm{~Hz})$ are analyzed [54] to establish anomalies or unaccounted perturbations of the earth's magnetic field before the occurrence of several earthquakes of interest [53]. Considering the development of such stations of great interest for possible applications in the field of early detection is considered as an emerging theme in the study.

(b) Other observatories had recorded signals in the $1 \mathrm{~Hz}$ to $50 / 60 \mathrm{~Hz}$ spectrum. The latter are important frequencies due to the presence of strong interference signals in this band [63]. It might be interesting to consider the different sub-bands within this range [64].

(c) There are also observatories that monitor the exact value of frequencies. Mainly, these values happen to be multiples of the principal frequency depending on the country. These frequencies are usually $223 \mathrm{~Hz}$ (in countries having $60 \mathrm{~Hz}$ as principal frequency) and $233 \mathrm{~Hz}$ (in countries having $50 \mathrm{~Hz}$ as principal frequency) [65]. Other observatories use a frequency of $17 \mathrm{~Hz}$ [66].

All of the observatories mentioned earlier measure signals of original nature, but there are other stations that monitor artificial signals that are generated by human activity, such as signals in the VLF band that are issued for the navigation aid [67].

Furthermore, not all of the stations have the same measuring devices. The most common are seismometers, acoustic meters, or telluric current meters. These instruments are of great importance to correlate the different parameters of interest with the detection of natural phenomena. The data above can be related to other meteorological data, such as wind speed, humidity, temperature, and atmospheric pressure [48].

Table 1 shows the World-Wide ELF/VLF observatories. This list is in descending order, showing the estimated station range according to the references listed in the table itself. The observatories with range above $1000 \mathrm{~km}$ are usually used for communications and shorter ranges are aimed for the detection of natural disasters. The station's sensitivity range is the maximum distance at which it can detect an atmospheric phenomenon. Therefore, this range depends on the magnitude of the different phenomena it can detect.

Table 1. Worldwide ELF (Extremely Low Frequency) Sensors.

\begin{tabular}{ccccccc}
\hline ID (Reference) & Name & Country & Lat $\left({ }^{\circ} \mathbf{N}\right)$ & Long $\left({ }^{\circ}\right.$ E) & Range (km) & Year \\
\hline HAS-(ARC) [68] & Hournsund & Arctic Pole & 77.8 & 20.7 & 500 & 2000 \\
KS(R) [69] & Kola & Russia & 68.8 & 34.5 & 7500 & 1999 \\
ES-(SW) [70] & Esrange & Sweden & 67.9 & 21.0 & 500 & 2000 \\
FS-(USA) [71] & Fairbanks & USA & 64.8 & -147.7 & 4000 & 1987 \\
LS-(R) [72] & Letha & Russia & 64.4 & 33.9 & 1000 & 2007 \\
GS-(R) [73] & Gakona & Russia & 62.7 & -143.9 & 5600 & 2012 \\
BS-(PO) [74] & Belsk & Poland & 51.8 & 20.7 & 550 & 1999 \\
NS-(H) [75] & Nagycenk & Hungry & 47.6 & 16.7 & 4400 & 2006 \\
MS-(J) [57] & Moshiri & Japan & 44.4 & 142.2 & 6000 & 1998 \\
HYS-(PO [76] & Hylaty & Poland & 42.2 & 22.5 & 320 & 1994 \\
RIS(USA) [75] & R. Island & USA & 41.7 & -71.6 & 4466 & 2007 \\
SS-(T) [77] & Sorköy & Turkey & 40.8 & 27.1 & 500 & 2007 \\
CAS-(SP) [60] & Calar Alto & Spain & 37.1 & -2.6 & 500 & 2012 \\
HS-(USA) [75] & Hollister & USA & 36.8 & -121.5 & 1500 & 1995 \\
KO-(J) [78] & Kakioka & Japan & 36.2 & 140.2 & 300 & 2006 \\
TO-(J) [75] & Tottori & Japan & 35.5 & 134.2 & 100 & 1973 \\
NO-(J) [48] & Nakatsugawa & Japan & 35.4 & 137.5 & 100 & 2000 \\
US-(J) [78] & Uchiura & Japan & 35.1 & 140.2 & 420 & 2012 \\
ISO-(J) [79] & Ibaraki & Japan & 34.8 & 135.6 & 200 & 1999 \\
\hline
\end{tabular}


Table 1. Cont.

\begin{tabular}{ccccccc}
\hline ID (Reference) & Name & Country & Lat $\left({ }^{\circ} \mathbf{N}\right)$ & Long $\left({ }^{\circ} \mathbf{E}\right)$ & Range $(\mathbf{k m})$ & Year \\
\hline OTS-(J) [49] & O. Tsushima & Japan & 34.6 & 129.4 & 1000 & 1998 \\
KAO-(R) [50] & Kamchatka & Russia & 32.9 & 158.2 & 50 & 2001 \\
NS-(IS) [75] & Negev & Israel & 30.6 & 35.0 & 660 & 1998 \\
MS-(MX) [80] & Mexico & Mexico & 19.8 & -101.7 & 500 & 2014 \\
AS-(IND) [81] & Allahabad & India & 16.1 & 81.7 & 4000 & 2007 \\
BAS-(ANT) [82] & Bellinshausen & Antarctic Pole & -62.2 & -59.0 & 1625 & 2007 \\
SPS-(ANT) [75] & South Pole & Antarctic Pole & -89.0 & 134.0 & 4000 & 1997 \\
\hline
\end{tabular}

In order to build the worldwide map of seismic events, records were used from the Significant Earthquake Database of National Oceanic and Atmospheric Administration (NOAA), containing information on destructive earthquakes from 2150 B.C. to the present day. All of the featured earthquakes meet at least one of the following: Moderate damage (at least 1 million dollars), 10 or more casualties, Magnitude 7.5 or greater, or the earthquake generated a tsunami [78]. More than 1400 earthquakes have been represented in this work, also considering those with tsunami associated.

These particular earthquakes that are accompanied with tsunami occurrence were selected among all others due to the fact that these events have produced huge disasters throughout the history. Thus, their detection is of great interest. The presentation of other earthquakes in the map would have made it much complex and difficult to read due to the high number of seismic events that have occurred in the considered period of time (the last two centuries). They wouldn't add relevant information as well, since the seismic zones are still active.

The previous data was laid out over a map, displaying recent seismic events of interest and the stations indicated in Table 1, with their corresponding detection range (as set by relevant literature). Figure 5 shows the final results. It is worth mentioning that annually, there are about one million earthquakes of $\mathrm{M}=2.0$ [83].

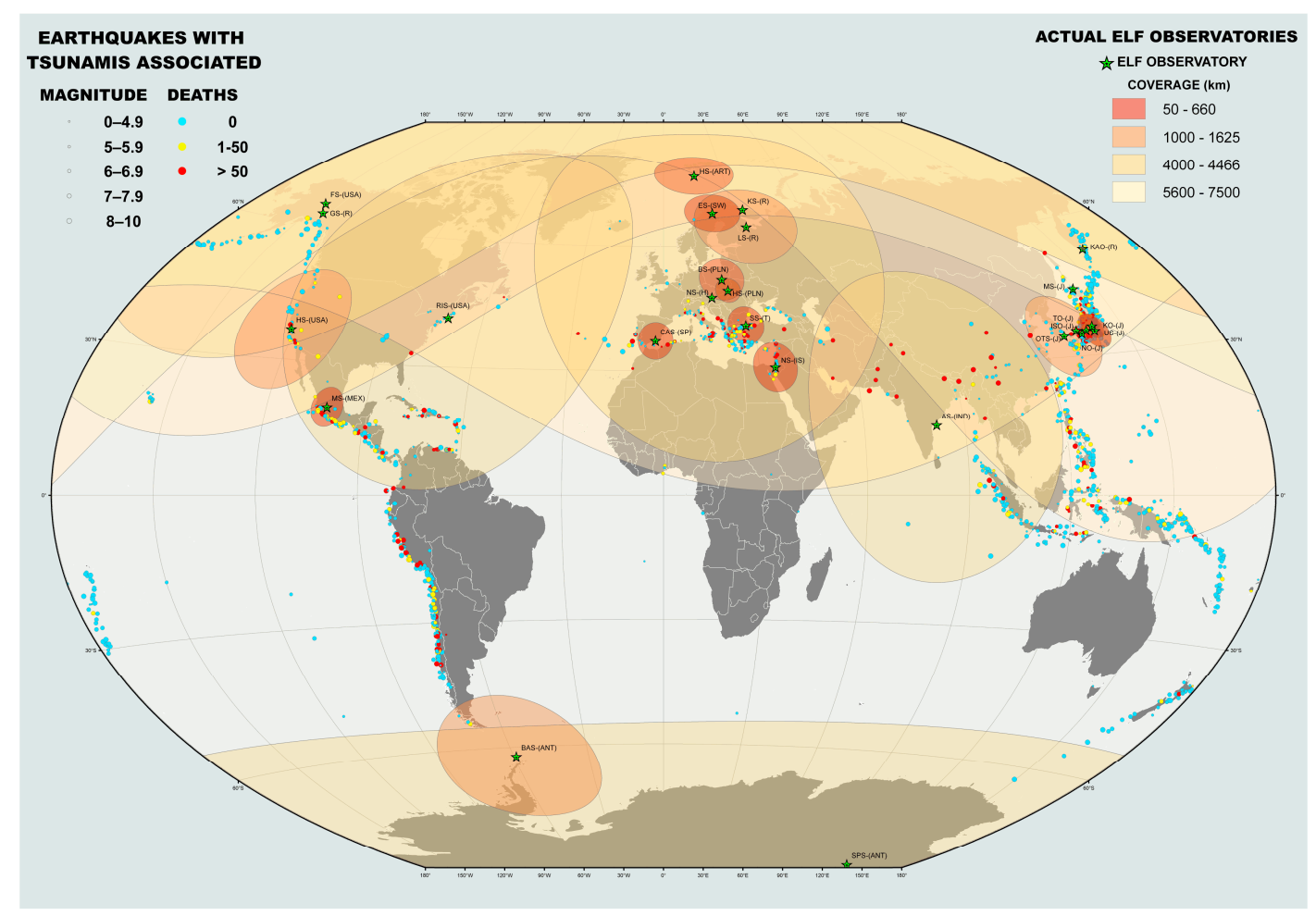

Figure 5. Tsunami risk alerts worldwide through ELF Sensors. 
The WinkelTripel projection has been used to build the map. The name Tripel (German for "triple") is a reference to Winkel's goal of reducing three kinds of distortion: area, direction, and distance. The WinkelTripel has the smallest skewness, so it is suited for mapping the entire world [84]. Nowadays it is found that this projection has been used to show the location of earthquakes recorded all over the earth, mainly due to the good representation of highest latitudes. It is used from 1998 by the National Geographic Society for worldwide maps [85], replacing the Robinson projection as the standard projection.

\section{Results and Discussion}

When considering Figure 5, we have developed several maps that are raised or propose new ELF sensors as stations to provide coverage to potentially vulnerable regions.

The label of "high seismic risk" could be tagged to the zones of Central America, Andes, the most oriental part of Europe, Philippines, Indonesia, and Japan, with the three last regions having a high occurrence of earthquakes and tsunami. There are frequent seismic events of great magnitude that involve high damages: the Sumatra Tsunami in 2010 [18] or the Tsunami Japan 2011 [51], and others. This is one of the reasons for which the study and analysis of this type of event is of great importance for the population. Figure 6 shows the current ELF stations along with the ELF stations, as proposed in Table 2. It can be observed that in this figure the coverage of the areas with seismic risk is greater than the one established in Figure 5, where there are only represented the existing ELF stations.

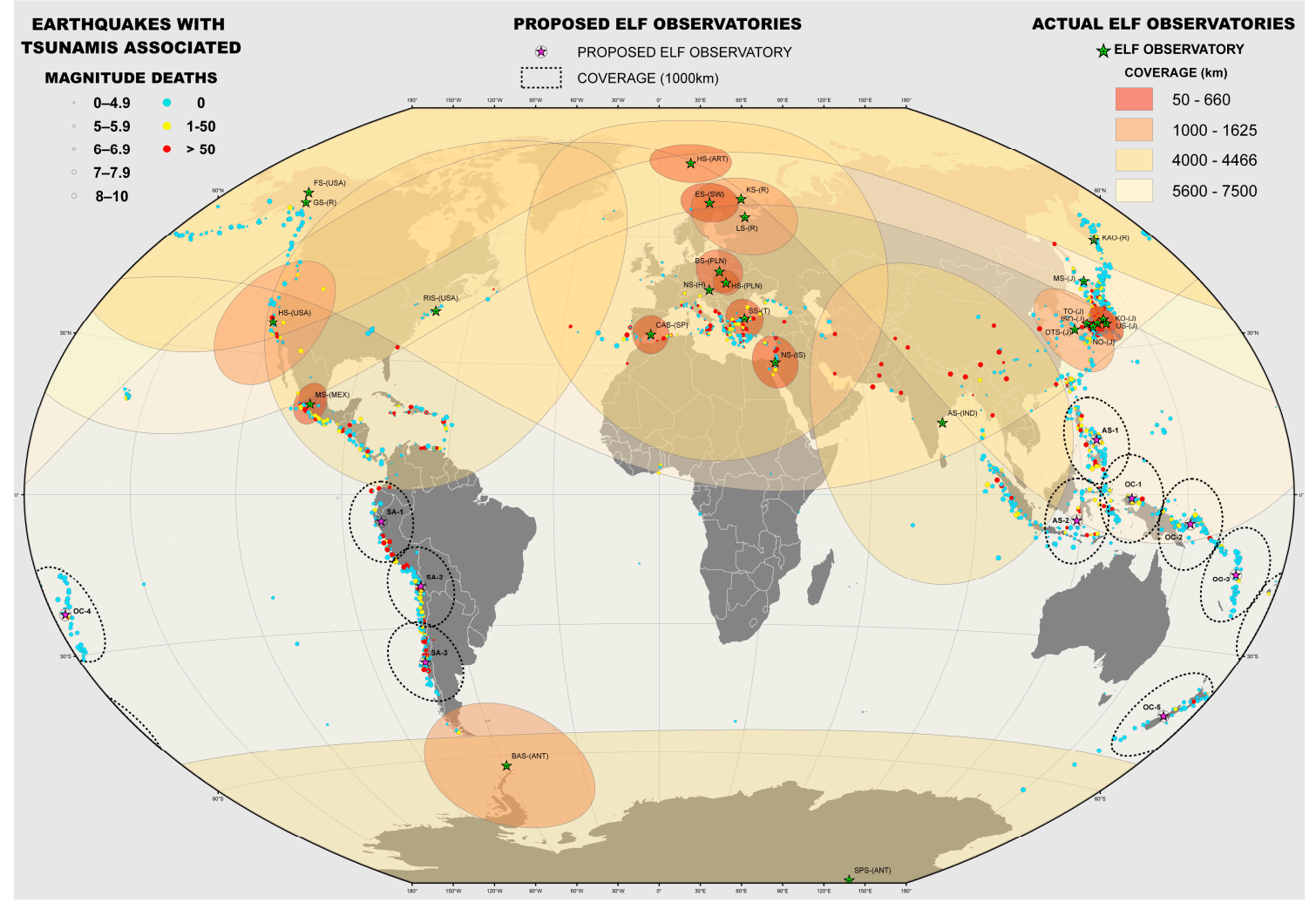

Figure 6. Tsunami risk alerts worldwide through proposed ELF observatories with a $1000 \mathrm{~km}$ of ratio. 
Table 2. Proposed ELF Observatories (1000 km).

\begin{tabular}{cccc}
\hline ID & Geographical Area & Lat $\left({ }^{\circ} \mathbf{N}\right)$ & Lon $\left({ }^{\circ} \mathbf{E}\right)$ \\
\hline AS-1 & Asia-Basey (Western Samar)-Philippines & 11.416 & 125.175 \\
OC-1 & Indonesia & -0.773 & 133.959 \\
AS-2 & Asia-Dewakang (Liukang) Indonesia & -5.490 & 118.630 \\
OC-2 & Oceania-Papua New Guinea & -5.809 & 151.002 \\
SA-1 & South America-Peru & -5.979 & -78.942 \\
OC-3 & Oceania-Malo Island (Vanuatu) & -15.25 & 166.83 \\
SA-2 & South America-Chile & -20.811 & -69.536 \\
OC-4 & Oceania-Tongatapu & -22.342 & -176.206 \\
SA-3 & South America-Chile & -37.724 & -73.260 \\
OC-5 & Oceania-New Zealand & -43.446 & 170.468 \\
\hline
\end{tabular}

Table 2 proposes with a minimum of 10 new ELF observatories to cover the seismic risk of all these areas of the earth, with a standard range of $1000 \mathrm{~km}$. With this range, all of the zones of interest could have been covered. So, South America can be covered by three observatories that located in Chile and Peru, while Oceania needs five observatories, and the south of Asia needs at least two of them.

If a smaller range is considered, the numbers of suggested stations should be higher, an example shown in Figure 7. In this figure the data in Table 3, where possible ELF stations are established to cover the vulnerable areas seismic coverage with a radius of $500 \mathrm{~km}$ are represented.

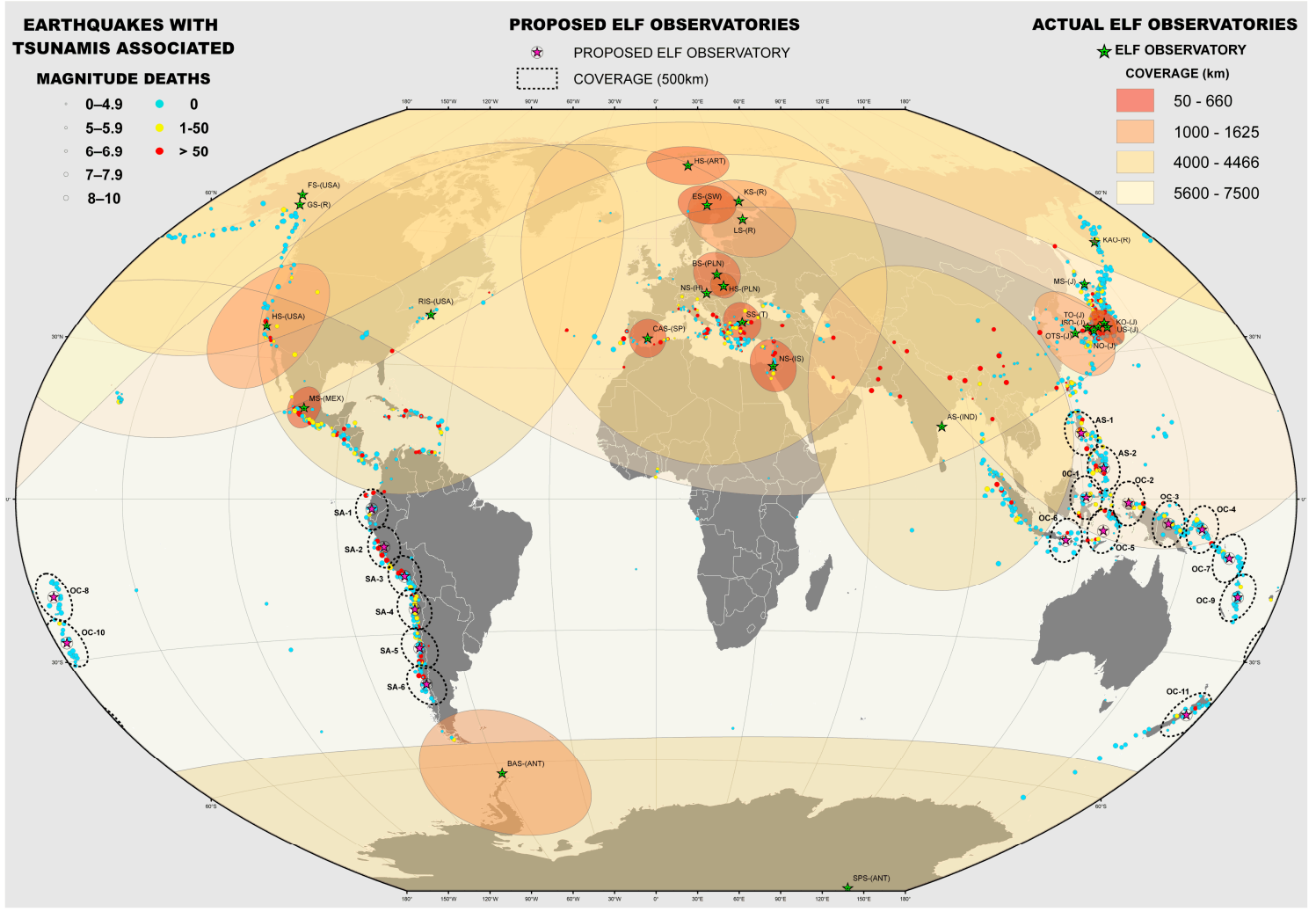

Figure 7. Tsunami risk alerts worldwide through proposed ELF observatories with a $500 \mathrm{~km}$ of radio. 
Table 3. Proposed ELF Observatories (500 km).

\begin{tabular}{cccc}
\hline ID & Geographical Area & Lat $\left({ }^{\circ} \mathbf{N}\right)$ & Lon $\left({ }^{\circ} \mathbf{E}\right)$ \\
\hline AS-1 & Philippines & 13.723 & 121.153 \\
AS-2 & Asia-Basey (Western Samar)_Philippines & 6.413 & 126.161 \\
OC-1 & Indonesia & 0.389 & 120.841 \\
OC-2 & Indonesia & -0.808 & 132.751 \\
OC-3 & Oceania-Papua New Guinea & -4.8817 & 144.243 \\
OC-4 & Oceania-Papua New Guinea & -5.8344 & 153.886 \\
OC-5 & Indonesia & -6.493 & 126.073 \\
OC-6 & Indonesia & -8.569 & 115.741 \\
SA-2 & South America-Peru & -10.500 & -77.000 \\
OC-7 & Oceania-Salomon Islands & -11.127 & 162.771 \\
SA-3 & South America-Peru & -17.000 & -72.000 \\
OC-8 & Oceania-Niue & -18.027 & -170.00 \\
OC-9 & Oceania-Malo Island (Vanuatu) & -18.421 & 168.411 \\
SA-1 & South America-Ecuador & -22.185 & -79.902 \\
SA-4 & South America-Chile & -24.537 & -70.707 \\
SA-5 & South America-Chile & -33.235 & -71.726 \\
OC-10 & Oceania-Tonga & -26.547 & -180.00 \\
OC-11 & Oceania-New Zealand & -41.25 & 175.00 \\
SA-6 & South America-Chile & -41.497 & -72.986 \\
\hline
\end{tabular}

The minimum number of stations to be considered in this case is 19 . So, South America can be covered by six observatories located in Chile, Peru, and Ecuador, while Oceania needs 11 observatories, and the south of Asia needs at least two of them.

There is no theoretical model that establishes a specific range for the detection of this type of phenomena, and appointed error in these measures. The ranges described in Table 1 were estimated empirically according to the sensitivity of the phenomena captured, with usual distances of between $500 \mathrm{~km}$ and $1000 \mathrm{~km}$. Consistent with these data, possible ELF stations with a range of $1000 \mathrm{~km}$ (Table 2) and $500 \mathrm{~km}$ (Table 3) have been proposed. The technology improvements allow for a greater sensitivity for the capture of these phenomena.

Recently, the largest number of the ELF observatories resides in the region of Japan; they cover the major part of its territory. The rest of observatories are distributed on the North American coast and Europe most commonly in its oriental zone.

In the Figure 5, it should be considered that the African continent has less seismic activity that can produce tsunami due to the localization of the tectonic plates, which makes it a stable zone. We can observe that there exist numerous zones in southern hemisphere, where the occurrence of seismic events is elevated. Currently, there are no ELF observatories in these zones, which make the prediction of seismic events possible and thus they are considered as vulnerable areas.

So, in Africa, there is no evidence of significant seismic events recorded and therefore installing ELF observatories would not be a priority, although it would be recommended. However, there are other areas of the world with high earthquake intensity and risk to human life as consequence to the high population density [86].

The low atmospheric attenuation with some latitude dependence of ELF signals (with an average of $0.64 \mathrm{~dB} / \mathrm{km}$ at $40 \mathrm{~Hz}$ ) allows for wave propagations at global scale [87]. Despite the global character of these signals, the signals anomalies related to the occurrence of seismic events cannot be detected whenever the magnitude is less than $6(\mathrm{M}<6)$. It should be considered that seismic phenomena of such magnitudes can also cause disasters and should be taken into account for their early detection [25]. This is one of the reasons behind the necessity of establishing new ELF stations in the potentially active regions, such as the Asian zone or the south of America.

The development of new ELF stations in areas of frequent seismic activity could be considered as a very useful tool for the possible detection of seismic phenomena. There are researchers with great 
experience in the correlation of seismograms with previous anomalies of the natural patterns of ELF signals. The author Hayakawa M. is one of the main advocates of this theory, as indicated by the large number of articles he has developed in this topic, although the list of researchers is rather extensive. Table 4 shows some of the precursor phenomena of seismic events, which have been observed in different earthquakes in recent years.

Table 4. Earthquake precursor phenomena.

\begin{tabular}{|c|c|c|}
\hline Precursor Phenomenon & Earthquake (Year) & Reference \\
\hline $\begin{array}{l}\text { Increase of Very Low Frequency/Extremely Low Frequency } \\
\text { (VLF/ELF) electromagnetic noise before and after an earthquake. }\end{array}$ & $\begin{array}{l}\text { Hyogo-Ken Nanbu earthquake } \\
\text { (1995) }\end{array}$ & [88] \\
\hline $\begin{array}{l}\text { Anomalous increases up to } 10 \mathrm{~Hz} \text { in Ultra Low Frequency (ULF) } \\
\text { signals were detected at Shigaraki, } 90 \mathrm{~km} \text { of the epicentre and at } \\
\text { Kokubunji, } 500 \mathrm{~km} \text { east of the epicentre. }\end{array}$ & $\begin{array}{l}\text { Hyogoken-Nanbu earthquake } \\
\text { (1995) }\end{array}$ & [89] \\
\hline $\begin{array}{l}\text { Strong ELF noise from lightning strikes } 2 \text { days before a } \\
\text { major earthquake. }\end{array}$ & $\begin{array}{c}\text { Hyogoken-Nanbu earthquake } \\
\text { (1995) }\end{array}$ & [90] \\
\hline $\begin{array}{l}\text { The anomalous and sporadic ionization of Earth's electric field } \\
\text { before major earthquakes. }\end{array}$ & $\begin{array}{c}\text { Hyogoken-Nanbu earthquake } \\
\text { (1995) }\end{array}$ & [91] \\
\hline $\begin{array}{l}\text { Observation of ULF anomalies prior to the development of } \\
\text { an earthquake. }\end{array}$ & Loma Prieta earthquake (1989) & {$[6,7]$} \\
\hline $\begin{array}{l}\text { A geomagnetic field variation of } 7.2 \mathrm{nT} \text { was detected } \\
\text { approximately } 7 \mathrm{~min} \text { before an earthquake. }\end{array}$ & Tohoku earthquake (2011) & {$[8-10]$} \\
\hline Detection of a series of pre-earthquakes magnetic anomalies. & Nepal earthquake (2015) & [11] \\
\hline $\begin{array}{l}\text { Abnormal variations in the amplitude and phase of these ELF } \\
\text { signals when crossing regions of certain seismic activity. }\end{array}$ & $\begin{array}{l}\text { earthquakes in Taiwan } \\
\text { (1999-2004) }\end{array}$ & [48] \\
\hline $\begin{array}{l}\text { An atypical amplitude increase of all its modes, highlighting the } \\
\text { variation in the fourth mode of resonance. }\end{array}$ & Chi-chi earthquake (1999) & [49] \\
\hline $\begin{array}{l}\text { The existence of depressions in the frequency of the fourth mode } \\
\text { resonance occurring between } 2 \text { and } 6 \text { days before one } \\
\text { of earthquakes. }\end{array}$ & $\begin{array}{l}\text { The Kamchatka region (during } \\
\text { the last } 30 \text { years) }\end{array}$ & [50] \\
\hline ELF Signals anomalies before an earthquake. & Sichuan earthquake (2008) & [52] \\
\hline ELF Signals anomalies before an earthquake. & Kobe earthquake (2013) & [53] \\
\hline Interference Signals in the ELF band. & Japan Earthquake (2011) & [64] \\
\hline
\end{tabular}

The table above shows that the number of earthquake precursor electromagnetic phenomena is high, and that the majority are due to anomalies in the signals that were captured in different ELF stations. Such anomalies comprise from the increase or decrease of the usual intensity of the signal, a shift in the frequency of some of its modes of resonance or the existence of signals considered as ELF noise, signals not usually be in this band.

It should be also considered that there is no exact methodology for the temporary detection of these precursory phenomena. Some have been observed for several minutes before an earthquake, others a few days before or even weeks. Therefore, it is an empirical methodology that depends on several factors, such as the magnitude of the seismic event, the proximity to the ELF station, its instrumentation, and even the existing environment. In spite of this, there is evidence that a continuous study of the patterns of ELF band signals (such as RS signal) can be a powerful methodology that allows for the possible early detection of important seismic phenomena.

A seismograph is capable of collecting seismograms from any earthquake $(M \approx 7)$ at any point on the earth. The filtering effect of the high seismic frequencies allows us to determine the remoteness of the earthquake and to center our study of correlation with the earthquakes located within a radius of between $500 \mathrm{~km}$ and $1000 \mathrm{~km}$, if it is located within range of a the ELF station. These are the estimated distances for the detection and correlation of the previous phenomena, as well as a possible explanation for the ELF stations performance ranges that are proposed in this paper. 
Correlation studies of the ELF signals captured at the Calar Alto station with data from the Alboran earthquake ( $M=6.3)$ [92], which occurred in January 2016, are being carried out. The results of this study may be adequate to extract quantitative conclusions of this methodology and to further strengthen its potential for the early detection of possible seismic events.

\section{Conclusions}

This paper shows the existing ELF stations and their experimental range of coverage, for the detection of seismic events. On the other hand, the earthquakes with related tsunamis that occurred throughout history were located. When considering the relationship between the detection of precursory electromagnetic phenomena and seismic events, this work highlights the lack of coverage for almost the entire southern hemisphere, warning the community about the seismic risk for the area of South America and South Asia for their high seismic activity. The location of ELF observatories is proposed to provide a minimum coverage of seismic risk alert worldwide, although this methodology is largely experimental and widely studied today.

The ELF stations proposed in this paper are set in the areas of the greatest potential risk in the development of high magnitude seismic events or damage to populated areas, depending on the experimental distances for detecting this kind of phenomena (500 km and $1000 \mathrm{~km})$. The proposed increase in the number of stations allows for greater potential comparative study and better behavior of these events. With this procedure, it should have carried out a greater number of works and the distribution scope is similar to the ones from other natural damage such as landslides, forest fires, and earthquakes studies to confirm and continue with the work that reinforces the use of these observing systems as a tool for early detection of seismic events of interest. So, the goal is to avoid possible global catastrophes with the related study of ELF signals of the observatories.

Despite that the relation between the detection of these seismic events and the ELF signals measurements (highlighting the Schumann resonance signal) is not totally verified; many studies are being contributed into investigation in the last few years. Works that showed anomalies or variations in these ELF signals a few weeks or days before the occurrence of large seismic events occur. These investigations are of interest due the major implications that can soon be developed through them soon. Therefore, this work opens new perspectives in the early detection of earthquakes and tsunamis in the world.

Acknowledgments: The Ministry of Economic and Competitiveness of Spain financed this work, under Project TEC2014-60132-P, in part by Innovation, Science and Enterprise, Andalusian Regional Government through the Electronics, Communications and Telemedicine TIC019 Research Group of the University of Almeria, Spain and in part by the European Union FEDER Program. We would to acknowledge to the Andalusian Geophysics Institute for sharing their amenities of Calar Alto with our ELF Observatory located in Almeria, Spain.

Author Contributions: Jose A. Gazquez, Rosa M. Garcia and Nuria N. Castellano formed the manuscript; Alberto-Jesus Perea-Moreno, Rosa M. Garcia and Francisco Manzano-Agugliaro developed the figures and tables; Jose A. Gazquez and Nuria N. Castellano contributed to the search of date and the realized of the maps; Manuel Fernandez-Ros provided the real ELF data by ELF station in Spain; Rosa M. Garcia, Alberto-Jesus Perea-Moreno, Francisco Manzano-Agugliaro and Nuria N. Castellano redacted the paper. Jose A. Gazquez checked the whole manuscript.

Conflicts of Interest: The authors declare no conflict of interest.

\section{Acronyms}

$\begin{array}{ll}\text { Acronym } & \text { Description } \\ \text { ELF } & \text { Extremely Low Frequency } \\ \text { M } & \text { Magnitude } \\ \text { ULF } & \text { Ultra Low Frequency } \\ \text { GPS } & \text { Global Positioning System } \\ \text { SHM } & \text { Structural Health Monitoring } \\ \text { VLF } & \text { Very Low Frequency }\end{array}$




$\begin{array}{ll}\text { OLR } & \text { Outgoing Long-wave Radiation } \\ B_{x}, B_{y} \text { and } B_{z} & \text { Magnetic Field vector Components } \\ \text { NS } & \text { North-South } \\ \text { EW } & \text { East-West } \\ \text { SR } & \text { Schumann Resonance } \\ \text { A/D } & \text { Analog/Digital } \\ \text { DSP } & \text { Digital Signal Processor } \\ \text { PSD } & \text { Power Spectral Density } \\ \text { FFT } & \text { Fast Fourier Transform } \\ \text { NOAA } & \text { National Oceanic and Atmospheric Administration }\end{array}$

\section{References}

1. Gusiakov, V.K. Relationship of tsunami intensity to source earthquake magnitude as retrieved from historical data. Pure Appl. Geophys. 2011, 168, 2033-2041. [CrossRef]

2. Sarlis, N.V.; Christopoulos, S.R.G.; Skordas, E.S. Minima of the fluctuations of the order parameter of global seismicity. Chaos 2015, 25, 063110. [CrossRef] [PubMed]

3. Ammon, C.J.; Kanamori, H.; Lay, T.; Velasco, A.A. The 17 July 2006 Java tsunami earthquake. Geophys. Res. Lett. 2006, 33, L24308. [CrossRef]

4. Geist, E.L.; Bilek, S.L.; Arco, D.; Titov, V.V. Differences in tsunami generation between the 26 December 2004 and 28 March 2005 Sumatra earthquakes. Earth Planets Space 2005, 58, 185-193. [CrossRef]

5. Varotsos, P. A review and analysis of electromagnetic precursory phenomena. Acta Geophys. Polonica 2001, 49, 1-42.

6. Fraser-Smith, A.C.; Bernardi, A.; McGill, P.R.; Ladd, M.E.; Helliwell, R.A.; Villard, O.G. Low-frequency magnetic field measurements near the epicenter of the Ms 7.1 Loma Prieta Earthquake. Geophys. Res. Lett. 1990, 17, 1465-1468. [CrossRef]

7. Bernardi, A.; Fraser-Smith, A.C.; McGill, P.R.; Villard, O.G. ULF magnetic field measurements near the epicenter of the Ms 7.1 Loma Prieta earthquake. Phys. Earth Planet. Inter. 1991, 68, 45-63. [CrossRef]

8. Utada, H.; Shimizu, H.; Ogawa, T.; Maeda, T.; Furumura, T.; Yamamoto, T.; Yamazaki, N.; Yoshitake, Y.; Nagamachi, S. Geomagnetic field changes in response to the 2011 off the Pacific Coast of Tohoku Earthquake and Tsunami. Earth Planet. Sci. Lett. 2011, 311, 11-27. [CrossRef]

9. Guangjing, X.; Peng, H.; Qinghua, H.; Katsumi, H.; Febty, F.; Hiroki, Y. Anomalous behaviors of geomagnetic diurnal variations prior to the 2011 off the Pacific coast of Tohoku earthquake (Mw9.0). J. Asian Earth Sci. 2013, 77, 59-65. [CrossRef]

10. Peng, H.; Katsumi, H.; Guangjing, X.; Ryo, A.; Chieh-Hung, C.; Febty, F.; Hiroki, Y. Further investigations of geomagnetic diurnal variations associated with the 2011 off the Pacific coast of Tohoku earthquake (Mw 9.0). J. Asian Earth Sci. 2015, 114, 321-326. [CrossRef]

11. De Santis, A.; Balasis, G.; Pavón-Carrasco, F.J.; Cianchini, G.; Mandea, M. Potential earthquake precursory pattern from space: The 2015 Nepal event as seen by magnetic Swarm satellites. Earth Planet. Sci. Lett. 2017, 461, 119-126. [CrossRef]

12. Harada, K.; Ishida, Y. Introduction to the Special Issue on "State-of-the-Art Sensor Technology in Japan 2012". Sensors 2014, 14, 11045-11048. [CrossRef] [PubMed]

13. Abidin, H.Z.; Santo, D.; Haroen, T.S.; Heryani, E. Post-Tsunami land administration reconstruction in Aceh: Aspects, status and problems. Surv. Rev. 2011, 43, 439-450. [CrossRef]

14. Abidin, H.Z.; Haroen, T.S.; Adiyanto, F.H.; Andreas, H.; Gumilar, I.; Mudita, I.; Soemarto, I. On the establishment and implementation of GPS CORS for cadastral surveying and mapping in Indonesia. Surv. Rev. 2015, 47, 61-70. [CrossRef]

15. Garrido-Villén, N.; Berné-Valero, J.L.; Antón-Merino, A.; Huang, C.Q. Displacement of GNSS permanent stations depending on the distance to the epicenter due to Japan's earthquake on 11 March 2011. Surv. Rev. 2013, 45, 159-165. [CrossRef]

16. Xu, C.J.; Fan, Q.B.; Wang, Q.; Yang, S.M.; Jiang, G.Y. Postseismic deformation after 2008 Wenchuan Earthquake. Surv. Rev. 2014, 46, 432-436. [CrossRef] 
17. Satirapod, C.; Simons, W.; Promthong, C.; Yousamran, S.; Trisirisatayawong, I. Deformation of Thailand as detected by GPS measurements due to the December 26th, 2004 mega-thrust earthquake. Surv. Rev. 2007, 39, 109-115. [CrossRef]

18. Panumastrakul, E.; Simons, W.J.F.; Satirapod, C. Modelling post-seismic displacements in Thai geodetic network due to the Sumatra-Andaman and Nias earthquakes using GPS observations. Surv. Rev. 2012, 44, 72-77. [CrossRef]

19. Tobin, H.J.; Kinoshita, M. Investigations of seismogenesis at the Nankai Trough, Japan. In Proceedings of the Integrated Ocean Drilling Program (IODP), Washington, DC, USA, 21 September-15 November 2007; Volume 314-316.

20. Plafker, G. Alaskan earthquake of 1964 and Chilean earthquake of 1960: Implications for arc tectonics. J. Geophys. Res. 1972, 77, 901-924. [CrossRef]

21. Kopp, H.; Kukowski, N. Backstop geometry and accretionary mechanics of the Sunda margin. Tectonics 2003, 22, 1072. [CrossRef]

22. Collot, J.Y.; Marcaillou, B.; Sage, F.; Michaud, F.; Agudelo, W.; Charvis, P.; Graindorge, D.; Gutscher, M.A.; Spence, G. Are rupture zone limits of great subduction earthquakes controlled by upper plate structures? Evidence from multichannel seismic reflection data acquired across the northern Ecuador-Southwest Colombia margin. J. Geophy. Res. 2004, 109, 1-14. [CrossRef]

23. Moore, G.F.; Bangs, N.L.; Taira, A.; Kuramoto, S.; Pangborn, E.; Tobin, H.J. Three-dimensional splay fault geometry and implications for tsunami generation. Science 2007, 318, 1128-1131. [CrossRef] [PubMed]

24. Hanson, J.A.; Bowman, J.R. Dispersive and reflected tsunami signals from the 2004 Indian Ocean tsunami observed on hydrophones and seismic stations. Geophys. Res. Lett. 2005, 32, L17608. [CrossRef]

25. Cochran, E.; Christensen, C.; Chung, A. A novel strong-motion seismic network for community participation in earthquake monitoring. IEEE Instrum. Meas. Mag. 2009, 12, 8-15. [CrossRef]

26. Grilli, S.T.; Taylor, O.D.S.; Baxter, C.D.; Maretzki, S. Aprobabilistic approach for determining submarine landslide tsunami hazard along the upper east coast of the United States. Mar. Geol. 2009, 264, 74-97. [CrossRef]

27. Burroughs, S.M.; Tebbens, S.F. Power law scaling and probabilistic forecasting of tsunami runup heights. Pure Appl. Geophys. 2005, 162, 331-342. [CrossRef]

28. Nakashima, Y.; Heki, K.; Takeo, A.; Cahyadi, M.N.; Aditiya, A.; Yoshizawa, K. Atmospheric resonant oscillations by the 2014 eruption of the Kelud volcano, Indonesia, observed with the ionospheric total electron contents and seismic signals. Earth Planet. Sci. Lett. 2016, 434, 112-116. [CrossRef]

29. Zhao, D.; Liu, Y.; Li, H. Self-Tuning Fuzzy Control for Seismic Protection of Smart Base-Isolated Buildings Subjected to Pulse-Type Near-Fault Earthquakes. Appl. Sci. 2017, 7, 185. [CrossRef]

30. Liu, Y.; Xu, C.; Wen, Y.; Li, Z. Post-Seismic Deformation from the $2009 \mathrm{Mw} 6.3$ Dachaidan Earthquake in the Northern Qaidam Basin Detected by Small Baseline Subset InSAR Technique. Sensors 2016, 16, 206. [CrossRef] [PubMed]

31. Lu, Z.; Wang, Z.; Li, J.; Huang, B. Studies on seismic performance of precast concrete columns with grouted splice sleeve. Appl. Sci. 2017, 7, 571. [CrossRef]

32. Xiangzeng, K.; Yaxin, B.; Glass, D.H. Detecting Seismic Anomalies in Outgoing Long-Wave Radiation Data. IEEE J.-STARS 2015, 8, 649-660.

33. Maurya, A.K.; Singh, R.; Kumar, S.; Veenadhari, B. VLF perturbations associated earthquake precursors using subionospheric VLF signals. In Proceedings of the 2014 XXXIth URSI General Assembly and Scientific Symposium (URSI GASS), Beijing, China, 16-23 August 2014.

34. Hayakawa, M.; Molchanov, O.A. Summary report of NASDA's earthquake remote sensing frontier project. Phys. Chem. Earth 2004, 29, 617-625. [CrossRef]

35. Varotsos, P.A.; Sarlis, N.V.; Skordas, E.S.; Uyeda, S.; Kamogawa, M. Natural-time analysis of critical phenomena: The case of seismicity. EPL Europhys. Lett. 2010, 92, 29002. [CrossRef]

36. Skordas, E.S.; Sarlis, N.V. On the anomalous changes of seismicity and geomagnetic field prior to the 2011 Mw 9.0 Tohoku earthquake. J. Asian Earth Sci. 2014, 80, 161-164. [CrossRef]

37. Chmyrev, V.; Smith, A.; Kataria, D.; Nesterov, B.; Owen, C.; Sammonds, P.; Sorokin, V.; Vallianatos, F. Detection and monitoring of earthquake precursors: TwinSat, a Russia-UK satellite project. Adv. Space Res. 2013, 52, 1135-1145. [CrossRef] 
38. Tsutsui, M. Behaviors of Electromagnetic Waves Directly Excited by Earthquakes. IEEE Geosci. Remote Sens. Lett. 2014, 11, 1961-1965. [CrossRef]

39. Fraser-Smith, A.C.; Helliwell, R.A. The Stanford University ELF/VLF Radiometer Project: Measurement of the Global Distribution of ELF/VLF Electromagnetic Noise. In Proceedings of the 1985 IEEE International Symposium on Electromagnetic Compatibility, Wakefield, MA, USA, 20-22 August 1985. [CrossRef]

40. Harrison, R.G.; Aplin, K.L.; Rycroft, M.J. Atmospheric electricity coupling between earthquake regions and the ionosphere. J. Atmos. Sol. -Terr. Phys. 2010, 72, 376-381. [CrossRef]

41. Ondoh, T. Investigation of precursory phenomena in the ionosphere, atmosphere and groundwater before large earthquakes of M > 6.5. Adv. Space Res. 2009, 43, 214-223. [CrossRef]

42. Schumann, W.O. Über die strahlungslosen Eigenschwingungen einer leitenden Kugel, die von einer Luftschicht und einer Ionosphärenhülle umgeben ist. Z. Naturforsch. A 1952, 7, 149-154. [CrossRef]

43. Balser, M.; Wagner, C.A. On frequency variations for the Earth-Ionosphere cavity modes. J. Geophys. Res. 1962, 67, 4081-4083. [CrossRef]

44. Nickolaenko, A.P.; Hayakawa, M.; Hobara, Y. Schumann Resonances and global lightning activity. In Proceedings of the International Conference on Mathematical Methods in Electromagnetic Theory, Kharkov, Ukraine, 2-5 June 1998; pp. 296-297.

45. Shvets, A.V. Solution of lightning intensity distance distribution reconstruction problem by using the Schumann Resonance signal. In Proceedings of the International Conference on Mathematical Methods in Electromagnetic Theory, Kharkov, Ukraine, 12-15 September 2000; pp. 589-591.

46. Simôes, F.; Rycroft, M.; Renno, N.; Yair, Y.; Aplin, K.L.; Takahashi, Y. Schumann Resonances as a means of investigating the electromagnetic environment in the solar system. Space Sci. Rev. 2008, 137, 455-471. [CrossRef]

47. William, E.R. Schumann Resonance: A global tropical thermometer. Science 1992, 256, 1184. [CrossRef] [PubMed]

48. Ohta, K.; Watanabe, N.; Hayakawa, M. Survey of anomalous Schumann resonance phenomena observed in Japan, in possible association with earthquakes in Taiwan. Phys. Chem. Earth 2006, 31, 397-402. [CrossRef]

49. Hayakawa, M.; Ohta, K.; Nickolaenko, A.P.; Ando, Y. Anomalous effect in Schumann resonance phenomena observed in Japan, possibly associated with the Chi-chi earthquake in Taiwan. Ann. Geophys. 2005, 23, 1335-1346. [CrossRef]

50. Uyeda, S.; Nagao, T.; Hattori, K.; Hayakawa, M.; Miyaki, K.; Molchanov, O.; Gladychev, V.; Baransky, L.; Chtchekotov, A.; Fedorov, E.; et al. Geophysical Observatory in Kamchatka region for monitoring of phenomena connected with seismic activity. Nat. Hazards Earth Syst. Sci. 2001, 1, 3-7. [CrossRef]

51. Kopytenko, Y.A.; Ismaguilow, V.S.; Hattori, K.; Hayakawa, M. Anomaly disturbances of the magnetic fields before the strong earthquake in Japan on 11 March 2011. Ann. Geophys. 2012, 55, 101-107.

52. Li, Q.; Schekotov, A.; Asano, T.; Hayakawa, M. On the Anomalies in ULF Magnetic Field Variations Prior to the 2008 Sichuan Earthquake. Open J. Earthq. Res. 2015, 4, 55-64. [CrossRef]

53. Schekotov, A.; Izutsu, J.; Hayakawa, M. On precursory ULF/ELF electromagnetic signatures for the Kobe earthquake on 12 April 2013. J. Asian Earth Sci. 2015, 114, 305-311. [CrossRef]

54. Nickolaenko, A.P. Application of the Hurst exponent in the analysis of natural ELF electromagnetic noise. In Proceedings of the International Conference on Mathematical Methods in Electromagnetic Theory, Kharkov, Ukraine, 12-15 September 2000; pp. 638-640.

55. Price, C. Lightning Sensors for Observing, Tracking and Nowcasting Severe Weather. Sensors 2008, 8, 157-170. [CrossRef] [PubMed]

56. Yano, M.; Yamashita, K.; Ida, Y.; Pavlovich, A. Ionospheric Monitoring by ELF Signals Received at Moshiri station in Japan. In Proceedings of the SICE Annual Conference, Tokyo, Japan, 20-22 August 2008; pp. 1678-1682.

57. Gladychevet, V.; Baransky, L.; Schekotov, A.; Fedorov, E.; Pokhotelov, O.; Andreevsky, S.; Rozhnoi, A.; Khabazin, Y.; Belyaev, G.; Gorbatikov, A.; et al. Study of electromagnetic emissions associated with seismic activity in Kamchatka region. Nat. Hazards Earth Syst. 2001, 1, 127-136. [CrossRef]

58. Nickolaenko, A.P.; Hayakawa, M.; Sekiguchi, M.; Ando, Y.; Ohta, K. Model modifications in Schumann resonance intensity caused by localized ionosphere disturbance over the earthquake epicenter. Ann. Geophys. 2006, 24, 567-575. [CrossRef] 
59. García, R.M.; Gázquez, J.A.; Castellano, N.N. Characterization of high-value inductors in ELF Band using vector newtwork analyzer. IEEE Trans. Instrum. Meas. 2013, 62, 415-423. [CrossRef]

60. Gázquez, J.A.; Fernández, M.; Castellano, N.N.; García, R.M. Techniques for Schumann Resonance Measurements: A Comparison of Four Amplifiers with a Noise Floor Estimate. IEEE Trans. Instrum. Meas. $2015,64,2759-2768$.

61. Soliman, A.M. New active RC configuration for realizing a medium-selectivity notch filter. Electron. Lett. 1972, 8, 522-524. [CrossRef]

62. Fernandez, M.; Gázquez, J.A.; García, R.M.; Castellano, N.N. Optimization of the periodogram average for the estimation of the power spectral density (PSD) of weak signals in the ELF band. Measurement 2016, 76, 207-218. [CrossRef]

63. Ohta, K.; Izutsu, J.; Hayakawa, M. Anomalous excitation of Schumann resonances and additional anomalous resonances before the 2004 Mid-Niigata prefecture earthquake and the 2007 Noto Hantou Earthquake. Phys. Chem. Earth 2009, 34, 441-448. [CrossRef]

64. Hayakawa, M. Seismo-Ionospheric Perturbations, and the Precursors to the 2011 Japan Earthquake. In Proceedings of the 2014 International Symposium on Electromagnetic Compatibility, Tokyo (EMC'14/Tokyo), Tokyo, Japan, 12-16 May 2014; pp. 155-158.

65. Yasukawa, H.; Adachi, S.; Hata, M.; Takumi, I. Signal detection and processing of seismic electromagnetic radiation in ELF band. In Proceedings of the 8th IEEE International Conference on Electronics, Circuits and Systems, St. Julian's, Malta, 2-5 September 2001; pp. 1477-1480.

66. Fujii, T.; Takumi, I.; Hata, M.; Yasukawa, H. Signal Processing of Earthquake Precursor at ELF Band. In Proceedings of the International Symposium on Communications and Information Technologies, Bangkok, Thailand, 18-20 October 2006; pp. 1-6.

67. Greenberg, E. Global geolocation of intense lightning strokes associated with TLEs based on ELF measurements from single-station. In Proceedings of the 23rd IEEE Convention of Electrical and Electronics Engineers in Israel, Tel-Aviv, Israel, 6-7 September 2004; pp. 25-28.

68. Schekotov, A.; Molchanov, O.; Hattori, K.; Fedorov, E.; Gladyshev, V.A.; Belyaev, G.G.; Chebrov, V.; Sinitsin, V.; Gordeev, E.; Hayakawa, M. Seismo-ionospheric depression of the ULF geomagnetic fluctuations at Kamchatka and Japan. Phys. Chem. Earth 2006, 31, 313-318. [CrossRef]

69. Tanaka, Y.T.; Hayakawa, M.; Hobara, Y.; Nickolaenko, A.P.; Yamashita, K.; Sato, M.; Takahashi, Y.; Terasawa, T.; Takahashi, T. Detection of transient ELF emission caused by the extremely intense cosmic gamma-ray flare of 27 December 2004. Geophys. Res. Lett. 2011, 38, L08805. [CrossRef]

70. Ferraro, A.J.; Lee, H.S.; Collins, T.W.; Baker, M.; Werner, D.; Zain, F.M.; Li, P.J. Measurements of extremely low frequency signals from modulation the polar electrojet above Fairbanks, Alaska. IEEE Trans. Antennas Propag. 1989, 37, 802-805. [CrossRef]

71. Nickolaenko, A.P. Diurnal Pattern of ELF Radio Signal Detected at the 'Bellinshausen' Antarctic Station. In Proceedings of the Sixth International Kharkov Symposium on Physics and Engineering of Microwaves, Millimeter and Submillimeter Waves and Workshop on Terahertz Technologies, Kharkov, Ukraine, 25-30 June 2007; pp. 760-762.

72. Yusop, N.; Ya'acob, N.; Shariff, K.K.M. Nighttime D-Region Ionosphere Characteristics from Tweek Atmospherics observed in the North America Region. In Proceedings of the IEEE Asia-Pacific Conference on Applied Electromagnetics (APACE), Melaka, Malaysia, 11-13 December 2012; pp. 104-109.

73. Nickolaenko, A.P.; Hayakawa, M. Algorithm for choosing the place for the global Schumann resonance observatory. Adv. Pol. Atmos. Res. 1999, 13, 119-131.

74. Matuszko, D.; Soroka, J. ZachmurzenieSpitsbergenunapodstawieobserwacji w PolskiejStacjiPolarnej w Hornsundzie. Cloudiness over Spitsbergen Based on Observations Made at the Polish Polar Station in Hornsund. 2013. Available online: http:/ / www.geo.uj.edu.pl (accessed on 12 March 2016).

75. Tulunaya, Y.; Altuntas, E.; Tulunay, E.; Price, C.; Ciloglu, T.; Bahadırlar, Y.; Şenalp, E.T. A case study on the ELF characterization of the earth-ionosphere cavity: Forecasting the Schumann resonance intensities. J. Atmos. Sol. -Terr. Phys. 2008, 70, 669-674. [CrossRef]

76. Neska, M.; Sátori, G.; Szendrõi, J.; Marianiuk, J.; Nowożyński, K.; Tomczyk, S. Schumann Resonance Observation in Polish Polar Station at Spitsbergen and Central Geophysical Observatory in Belsk. Publ. Inst. Geophys. Pol. Acad. Sci. 2007, C-99, 1-6. 
77. Yasakawa, H.; Adachi, S.; Takamu, I.; Hata, M. Auditory sonification for ELF band signal of seismic electromagnetic radiation. Geosci. Remote Sens. Symp. 2000, 1, 301-303.

78. National Geophysical Data Center. World Data Service (NGDC/WDS): Significant Earthquake Database; National Geophysical Data Center, NOAA: Silver Spring, MD, USA, 2015. [CrossRef]

79. Sierra, F.P.; Vázquez, H.S.; Andrade, M.E.; Rodriguez-Osorio, D. Development of a Schumann-resonance station in Mexico: Preliminary measurements. IEEE Antennas Propag. Mag. 2014, 56, 112-119. [CrossRef]

80. Maurya, A.K.; Selvakumaran, R.; Singh, R.; Veenadhari, B. Characteristics of Tweeks Radio Atmospherics Observed in Indian Low Latitude region using AWESOME VLF receiver. In Proceedings of the XXXth URSI General Assembly and Scientific Symposium, Istanbul, Turkey, 13-20 August 2011; pp. 1-4.

81. Hayakawa, M.; Hobara, Y.; Ohta, K.; Izutsu, J.; Nickolaenko, A.P.; Sorokin, V. Seismogenic effects in the ELF Schumann resonance band. IEEJ Trans. Fundam. Mater. 2011, 131, 684-690. [CrossRef]

82. Kulak, A.; Kubisz, J.; Klucjasz, S.; Michalec, A.; Mlynarczyk, J.; Nieckarz, Z.; Ostrowski, M.; Zieba, S. Extremely low frequency electromagnetic field measurements at the Hylaty station and methodology of signal analysis. Radio Sci. 2014, 49, 361-370. [CrossRef]

83. Fernández-Gómez, M.J.; Asencio-Cortés, G.; Troncoso, A.; Martínez-Álvarez, F. Large Earthquake Magnitude Prediction in Chile with Imbalanced Classifiers and Ensemble Learning. Appl. Sci. 2017, 7, 625. [CrossRef]

84. Goldberg, D.M.; Gott, J.R. Flexion and skewness in map projections of the earth. Cartographica 2007, 42, 297-318. [CrossRef]

85. Okal, E.A. The quest for wisdom: Lessons from 17 tsunamis, 2004-2014. Philos. Trans. 2015, 373. [CrossRef] [PubMed]

86. Hennig, B.D. Gridded cartograms as a method for visualizing earthquake risk at the global scale. J. Maps 2014, 10, 186-194. [CrossRef]

87. Burke, C.P.; Jones, D.L. An experimental investigation of ELF attenuation rates in the Earth-ionosphere duct. J. Atmos. Sol. -Terr. Phys. 1992, 3-4, 243-250. [CrossRef]

88. Hayakawa, M. (Ed.) Atmospheric and Ionospheric Electromagnetic Phenomena Associated with Earthquakes; TERRAPUB: Tokyo, Japan, 1999; pp. 417-427.

89. Ondoh, T. Anomalous sporadic-E ionization before a great earthquake. Adv. Space Res. 2004, 34, 1830-1835. [CrossRef]

90. Hata, M.; Fujii, T.; Takumi, I. EM precursor of large-scale earthquakes in Japan. In Proceedings of the International Workshop on Seismo Electromagnetics (IWSE 2005); University Electro-Communications: Tokyo, Japan, 2005; pp. 182-186.

91. Hayakawa, M.; Molchanov, O.A. Seismo Electromagnetics: Lithosphere-Atmosphere-Ionosphere Couplings; TERRAPUB: Tokyo, Japan, 2002; pp. 385-390.

92. Geological and Mining Institute of Spain. A 6.3 Earthquake in the Alborán Sea Sha kes Andalusia and Melilla. 2016. Available online: http:/ /info.igme.es/eventos/TerremotoAlboran (accessed on 16 October 2017). 